\title{
Effect of Nurse Managers' Leadership Styles on Organizational Commitment of Nurses Working at Taif Governmental Hospitals in Kingdom of Saudi Arabia
}

\author{
Dr. Mervat Ebrahim Aly El Dahshan ${ }^{1}$ Dr. Hanan A. M. Youssef ${ }^{2}$ Mohammad Aljouaid $^{3}$ \\ Rabia A. Babkeir ${ }^{4}$ Dr. Wisal B. Hassan ${ }^{5}$ \\ ${ }^{I}$ (Nursing Department, College of Applied Medical Sciences / Taif University, Saudi Arabia) \\ ${ }^{I}$ (Nursing Administration Department, Faculty of Nursing/Menoufiya University, Egypt) \\ ${ }_{2}^{2}$ (Nursing Department, College of Applied Medical Sciences / Taif University, Saudi Arabia) \\ ${ }_{3,4}$ (Nursing Department, College of Applied Medical Sciences / Taif University, Saudi Arabia) \\ ${ }_{5}^{5}$ (Radiological Sciences Department, College of Applied Medical Sciences / Taif University, Saudi Arabia)
}

\begin{abstract}
Leadership is the foundation of organizational commitment and has been recognized in researches to promote organizational commitment, employee job satisfaction and improved individual productivity which in turn lead to organizational success. By using appropriate leadership style, leaders can influence their employees' organizational commitment positively. Aim: To explore and describe nurse managers' leadership styles and its effect on nurses' organizational commitment at Taif governmental hospitals in Kingdom of Saudi Arabia. Subjects and methods: A cross sectional descriptive survey study was conducted in two selected hospitals, King Abdul Aziz and King Faisal hospitals. Leadership Styles and Organization Commitment Questionnaires were used and distributed to 570 nurses. Results: The present study's findings revealed that most of leaders in the two selected hospitals use both leadership styles from nurses perspectives. The great majority of studied nurses had commitment to their organization, whereas, only small percentage of them didn't have commitment to their organization in the two selected hospitals. Conclusions: Transformational leadership style was rated higher than transactional leadership style in both hospitals, and there were statistically significant positive correlations between the perceived leadership styles and organizational commitment. Recommendations: Designing and implementing a comprehensive training program to managers and leaders to encourage behaviors such as trust creation, encouragement of creativity, and induction of a common vision. Such managers can play a key role in the development of organizational commitment of their employees.
\end{abstract}

Keywords: Transformational Leadership, Transactional Leadership, Organizational Commitment.

\section{Introduction}

Leadership has been always a crucial issue and function of management since organizations and companies are permanently in a constant struggle to be increasingly competitive which helps to maximize efficiency and to achieve organizational goals (Keskes, 2014). Nursing leadership is pivotal because nurses represent the most extensive discipline in health care (Marquis \& Huston, 2015). Nursing leaders currently face many challenges (new roles, new technology, financial constraints, greater emphasis on participation, cultural diversity, and education). In every health care institution, the leadership must act to encourage effecting changes and achieving high standards of the patient care (Sullivan \& Garland, 2010). Huber (2014) defined leadership as the process of working with individuals, groups, and other resources in order to achieve the objectives of the organization (Lorber et al., 2016). Leadership style is the most prevalent factors that influence employees' attitudes and behaviors including organizational commitment (Alkahtani, 2016). It is the approach of providing direction, implementing plans, and motivating people (Northouse, 2015).

Leaders can influence the behavior of their followers through the use of different styles, or approaches, to manage others. For the past three decades, a pair of predominant leadership styles (transactional and transformational leadership) has received a significant amount of attention (Keskes, 2014). Transformational leadership is a process in which "leaders and followers raise one another to higher levels of motivation and morality". This motivation is supposed to stimulate people to accomplish beyond expectancy by generating belongingness in achieving the vision (Foon, 2016). Transformational leadership embraced the assumption that people have immerse potential and can be successful if they are given the vision and support from highly engaging, positive and inspiring leaders (Gates, 2009). Through motivation, a change process happens and subordinates become encouraged and are enthusiastic in achieving organizational goals and objectives (Foon, 2016). From another point of view, transformational leadership is generally defined as a process whereby leaders take conscious action to develop followers into leaders, exhibit behaviors that elicit trust, display selfsacrificial perspectives to build commitment and influence, and demonstrate a moral compass towards mission 
and purpose ( Porter, 2015). Transformational leaders are often highly visible and known for their passion and energy in all aspects of their work. They spend most of their time communicating with others and looking for initiatives that add value to their teams' future. Transformational leaders motivate and empower their followers, often transcending short-term goals by focusing on higher order intrinsic needs ( Kuria et al., 2016). In this leadership style, the leaders tend to place followers' needs over their own needs. Transformational leaders influence the beliefs and attitudes of followers to align with theirs and then direct followers towards the attainment of greater organizational success ( Alshahrani and Baig, 2016).

Transformational leadership can be divided into four components, which are idealized influence, Individualized Consideration, Inspirational Motivation and Intellectual Stimulation. Idealized Influence is the behavior that encourages the followers to use their leaders as role models. Idealized influence leaders have high moral and ethical values and are able to provide their followers with a sense of vision and mission. In most situations, followers greatly respect the idealized influence leader (Northouse, 2015). Individualized Consideration is shown by the transformational leader by creating a supportive climate, listening to their employees, and acts as a coach and mentor which the leaders show consideration for their employees' needs. Leaders pay close attention to individual differences and treat their employees in the most caring way. They also help individuals to achieve goals and personal development. This type of leaders also uses delegation to get their employee to grow through personal challenges (Alkahtani, 2016).

Inspirational Motivation is about raising the consciousness of the employees by motivating and inspiring them to demonstrate commitment to the vision and mission of the group in the organization. The inspirational motivational leaders engage in clearly communicating high expectations to followers and increase team spirit and enthusiasm (Northouse, 2015). Intellectual Stimulation is demonstrated by the leaders when they support their employees to be creative and innovative and to try new approaches and challenge their own beliefs and values. This type of leaders promotes problem solving to find creative solutions (Alkahtani, 2016).

Transactional leadership which is also known as associate leadership requires establishment of relations between the leader and those employees who work under the leader supervision. These employees will receive their desired rewards in return for implementation of their missions ( Ahmadi et al., 2012). Transactional leadership can be described as "keeping the ship afloat." Transactional leaders use disciplinary power and an array of incentives to motivate employees to perform at their best. The term "transactional" refers to the fact that this type of leader essentially motivates subordinates by exchanging rewards for performance. A transactional leader generally does not look ahead in strategically guiding an organization to a position of market leadership; instead, these managers are solely concerned with making sure everything flows smoothly today ( Ingram, 2016).

Transactional leadership refers to a dynamic exchange between leaders and their subordinates, in which the leader establishes specific goals, monitors progress, and identifies rewards that can be expected upon goal achievement. It involves an exchange process between the leader and the followers, intended to increase followers' compliance to the leader and to the organizational rules ((Keskes, 2014). The transactional leadership is based on the exchange process that involves fulfilling contractual obligations, setting objectives and monitoring and controlling outcomes. This leadership style is made up of three main factors: contingent reward and management by exception (active) and management by exception (passive) (Foon, 2016).

Contingent Reward Managers who use the contingent reward leadership show the standards, and encourage their employees to perform well because the leaders will let their employees know the rewards they will receive if their performance level is high. Subordinates are promised rewards for good performance but if the performance is bad they will receive the punishment. Management by Exception (Active) occurs when leaders make corrective criticisms or use negative reinforcement. This leadership behavior monitors employees closely in order to identify mistakes and errors. Leaders with Management-by- Exception "active" behaviors are characterized as monitoring followers' performances and taking corrective action if deviations from the set standards occur. These leaders enforce rules to avoid mistakes (Alkahtani, 2016).

Management by Exception (Passive), in this leadership style, leaders use Management-by-Exception (passive), only intervene when goals have not been met or a problem arises. This leader with a "passive" behavior would not get involved until problems become serious. The Management-by-Exception (passive) leaders wait to take action until mistakes are brought to their attention (Northouse, 2015). Transactional leadership concerns the power to perform certain tasks and reward or punish for employees' performance. It gives the opportunity to leaders to lead the employees and they agree to follow their leaders to accomplish the goals. Power is given to the leaders to evaluate, train, correct and handle the employees when productivity is below the expectation level and reward appropriately when the expected outcome is reached (Alkahtani, 2016).

Abualrub and Alghamdi (2012) examined the impact of leadership styles of nurse managers on Saudi nurses' job satisfaction and intention to stay on the job. The results indicated that Saudi nurses perceived their managers as transformational rather than transactional leaders. Another study conducted by Malloy and 
Penpras ( 2010) suggested that leaders using the components of transformational leadership more likely contribute to a positive work environment, increased job satisfaction, commitment and motivation.

Organizational commitment is a common phenomenon which has been extensively addressed by many researchers worldwide due to its importance to the organization (Alkahtani, 2016). In the meantime, over the past two decades, organizational commitment was the dominant job attitude that has been the center of attention of researchers and the subject of so many meta-analyses (Haghighy et al., 2016). Today, healthcare organizations are challenged by the lack of commitment from nurses and doctors due to their choices to leave the organization (Fabiene and Kachchhap, 2016). Committed employees are expected to perform at a greater level than their uncommitted counterparts. The lack of commitment among employees of an organization results in interruptions in normal operations, loss of efficiency and increase customer dissatisfaction while high levels of commitment to the organization are likely to reduce staff absenteeism, and increase levels of job performance ( Soha et al., 2016).

Commitment is defined as the psychological bond that is characterized by the members' feeling of attachment, obligation, and loyalty to a given organization. Commitment also describes the level of employees' acceptance of the organization's goals and the willingness they have to work towards these goals (Manetje and Martins, 2009 \& Fabiene and Kachchhap, 2016). Organizational commitment is categorized into three components; affective, continuance and normative commitments. Affective commitment concerns the employee's emotional attachment to, identification with and involvement in the organization ( Kimura, 2013). Continuance commitment, on the other hand, refers to employees' assessment of whether the costs of leaving the organization are greater than the costs of staying. Employees who perceive that the costs of leaving the organization are greater than the costs of staying will remain with the organization (Rego et al., 2016). Normative commitment refers to employees' feelings of responsibility to the organization. Employees with high levels of normative commitment stay with the organization because they feel that they have to (Alkahtani, 2016 and Sow et al., 2016).

In arguing for this framework, Allen and Meyer (1997) contended that affective, continuance, and normative commitment were components rather than types because employees could have varying degrees of all three. They exemplified the three types of commitment by saying that one employee might feel both a strong attachment to an organization and a sense of responsibility to remain. A second employee might enjoy working for the organization but also recognize that leaving would be very difficult from an economic perspective. Finally, a third employee might experience a considerable degree of desire, need, and responsibility to remain with the current employer (Alkahtani, 2016).

Nurses are the backbone of medical care, hence the nursing leaders should build and maintain a healthy work environment that motivates and supports the nurses to reduce nurses turnover and increase organizational commitment. It has been found that the nurses prefer to work in an environment which promotes social relationship and encourages participation in decision-making (Alshahrani and Baig, 2016). By implementing transformational leadership styles, subordinates feel empowered leading to organizational commitment and solving of employee morale problems which in turn lead to job satisfaction (Foon, 2016).

Over the years, there has been increasing interest in the relationship between leadership and organizational commitment. In a study of Kenyan and US financial firms, Walumbwa et al., (2005) found that transformational leadership not only had a positive effect on organizational commitment but on job satisfaction as well. Transformational leaders influence followers' organizational commitment by encouraging followers to think critically by using novel approaches, involving followers in decision-making processes, inspiring loyalty, while recognizing and appreciating the different needs of each follower to develop his or her personal potential (Keskes, 2014). Lee (2004) found out that transformational leadership correlates significantly with organizational commitment with samples of research and development professional in Singapore. Contrary, transactional leadership does not have significant relationship with organizational commitment.

\section{Significance of the study:}

In the recent years organizations have gone through dramatic changes, including flatter and looser structures, downsizing, and horizontal approaches to information flow, these changes are due to rapid technological developments, global competition, and the changing nature of the workforce that triggered by interventions such as total quality management and business process reengineering. Leadership is regarded as a critical factor in the initiation and implementation of the transformations in the organizations. The leadership should be broadened if it wants to engender a positive impact on individuals, teams, and organizations (Raja \& Alanichamy, 2011).

Healthcare organizations are systems where human resources are the most important assets for the delivery of quality healthcare; nursing is the largest workforce within the healthcare organization. They are the front line healthcare providers who spend more time with patients than any other healthcare professional. Therefore achieving optimal healthcare delivery is difficult, if not impossible without the efforts and 
commitment of staff nurses. Nursing leadership has a significant impact on creating practice environments that support and motivate staff nurses to provide the highest level of care to healthcare consumers (Fugate, 2014). Therefore, the current study will enhance our understanding of the relationship between leadership styles and organizational commitment that affect work behaviors and attitudes of nurses which would ultimately be linked with the achievement of organizational goals.

\author{
Aim of the Study: \\ The main aim of the present study was to: \\ Explore and describe nurse managers' leadership styles and its effect on nurses' organizational commitment at \\ Taif governmental hospitals in Kingdom of Saudi Arabia.

\section{Research questions:} \\ 1. What is the nurse managers' leadership style as perceived by their subordinates? \\ 2. What is nurses' organizational commitment? \\ 3. What is the correlation between nurse managers' leadership styles and nurses' organizational commitment?
}

\title{
Research design:
}

\section{Subjects and Methods}

Non-experimental cross sectional correlational study for exploring and describing nurse managers' leadership styles and its effect on nurses' organizational commitment at Taif governmental hospitals in Kingdom of Saudi Arabia was conducted.

\section{Settings:}

The study was conducted in two different hospitals (King Faisal Specialized Hospital $\{$ KFSH $\}$ \& King AbdulAziz Specialized Hospital $\{\mathrm{KASH}\})$.

\section{Subjects of the study:}

A random sample of 570 nurses worked in the previously mentioned settings (King Faisal Specialized Hospital $\{\mathrm{KFSH}\} \&$ King Abdul-Aziz Specialized Hospital $\{\mathrm{KASH}\})$ were selected.

\section{Inclusion criteria:}

Staff nurses who have at least one year of experience and working at study settings, and as well as agreed to participate in this study.

\section{Instrumentation:}

In order to fulfill the aim of the study, three modified questionnaires were used to measure the variables in this study from nurses' point of view, which include:

1. Assessment Sheet: This sheet was designed by the researchers to collect the socio- demographic data (such as; age, gender, qualification, total years of experiences, hospital, nationality and marital status).

2. Leadership Style Questionnaire: This tool was used to measure transactional and transformational leadership styles from nurses' point of view. It was developed by Vera and Crossan, (2004). It is modified and translated into Arabic by the researchers. The questionnaire included 18 statements concerning transformational and transactional leadership styles. Twelve statements concerning transformational leadership style and six statements measuring transactional leadership style. Each item was measured on a 5- point Likert scale. The possible responses ranged from 1 (strongly disagree) to 5 (strongly agree) on all items. The higher the scores, the higher the leadership is.

3. Organization Commitment Questionnaire: This is a self-reporting 18 items scale developed by Meyer (2004) used to measure nurses' commitment toward their organizations. It included statements reflecting nurses' perception of three types of commitment namely; affective commitment (6 statements), continuance commitment (6 statements); and normative commitment ( 6 statements). The responses were made on a 5 point Likert scale ranging from 1 (strongly disagree) to 5 (strongly agree). The higher the scores, the higher the commitment is. There were four items on the commitment scales had been worded such that strong agreement actually reflects a lower level of commitment. These are referred to as "reverse-keyed" items (identified by " $R$ " after the statement).

\section{Pilot study:}

A pilot study was performed on twenty nurses (not included in the full-scale study) to test the practicability and applicability of the tool, identify any difficulties, estimate the time needed to fill in the questionnaire. Based on the results of the pilot study, the necessary modification and clarification of some questions were done. Validity and reliability of the study tool was tested using Cronbach's coefficient alpha (0.84).

\section{Method of Data collection:}

Approval of institutional review board (IRB) at the selected hospitals was obtained. After that, once the subjects were asked to sign the designed consent form, then the researcher gave the questionnaire for filling it out, each participant was spent 20-30 minutes to complete the questionnaire. The researcher told the participants that all 
information that will be gathered will be used only for the purpose of research, and results of the study will be published in aggregates. The data collection phase of the study was carried out in three months from 1/10/2016 to $30 / 12 / 2016$.

\section{Ethics and human rights:}

An informed consent was obtained from all the participants before collecting any data. Explanation of the study aim in a simple and clear manner was done to each participant. All data was considered confidential. Participants were informed about their rights to withdraw from the study at any time without giving any reason.

\section{Data Analysis Plan:}

Data were revised, coded, entered, analyzed and tabulated using SPSS version 19. Both descriptive statistics (frequency, percentage, mean and standard deviation) and inferential statistics (Pearson correlation and chisquare tests) were used according to type of variables. $\mathrm{P}$ value less than 0.05 was considered significant.

\section{Limitation of the study:}

The most remarkable limitation of the present study was that all data in this study was obtained through crosssectional, self-report surveys, which could lead to common method variance between predictor variables and outcome variables. Therefore, it is suggested that these results be used cautiously.

\section{Results}

The current challenges facing healthcare systems, in relation to the shortage of health professionals, necessitates mangers and leaders to learn from different leadership styles and staff empowerment strategies, so as to create a work environment that encourages nursing staff commitment to patients and their organization. This study intends to explore and describe nurse managers' leadership styles and its effect on nurses' organizational commitment at Taif governmental hospitals in Kingdom of Saudi Arabia. Figure 1 illustrated distribution of studied nurses by type of hospital. (51.6\%) of participant nurses, were from King Faisal hospital while (48.4\%) from King Abdul Aziz hospital.

Table (1: A and B) demonstrated socio- demographic characteristics of participant nurses, the mean age of participant nurses were $(28.7 \pm 2.9$ and 30.1 \pm 5.2 years) in King Abdul Aziz and King Faisal hospital respectively and most of them $(72.6 \%)$ were female. Regarding occupation $(82.8 \%)$ of participant nurses were staff nurses while (17.2\%) of them were nurse managers. The mean years of experience of participant nurses,

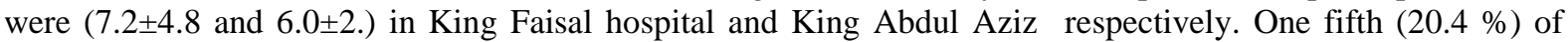
participant nurses had a diploma degree, while $(71.9 \%)$ of them were bachelor degree. Above half of participant nurses $(51.2 \%)$ were Non-Saudi and married $(56.8 \%)$. There is statistically significant difference between the two hospitals regarding all socio- demographic characteristics.

Table 2 showed leadership styles of nurse managers distributed by type of hospital. As noticed from the table, most of participant nurses (74.4\%) perceived their leaders as transformational leaders in both hospitals and the difference between the two hospitals were statistically significant, $\mathrm{P}=0.000$. Regarding transactional leadership style, $(65.6 \%)$ of participant nurses perceived their leaders as transactional leaders in both hospitals and there is no statistically significant difference between the two hospitals $\mathrm{P}=0.10$.

As shown in the table 3, nurses' affective organizational commitment, the majority of them $(78.6 \%)$ had affective commitment to their organization, while nearly about one fifth of them (21.4\%) didn't have commitment to their organization in both hospitals. Moreover, affective commitment was higher in King Faisal hospital than King Abdul Aziz hospital and differences between them were statistically significant, $\mathrm{P}=0.001$.

Continuance organizational commitment of nurses is illustrated in table 4. It is clear that the highest percentage $(84.2 \%)$ of participant nurses had continuance commitment to their organization and about $(15.8 \%)$ of them didn't have in both hospitals. Regarding hospitals, continuance commitment was higher in King Faisal hospital (89.8\%) compared to King Abdul Aziz hospital (78.3\%) and the differences between them were statistically significant, $\mathrm{P}=0.000$.

Table 5 represented nurses' normative organizational commitment. (71.6\%) of participant nurses had normative commitment to their organization, while only (28.4\%) of them didn't have normative commitment to their organization in both hospitals. Concerning hospital, normative commitment was higher in King Abdul Aziz than King Faisal hospital and there were statistically significant differences between the two hospitals $\mathrm{P}=0.000$.

Figure 2 showed nurses' total organizational commitment distributed by types of hospital. As evident from this figure, the great majority $(87.1 \%)$ of participant nurses had commitment to their organization. Moreover, only (12.9\%) didn't have commitment to their organization in King Faisal hospital. On the other hand, in King Abdul Aziz hospital, the majority (76.8\%) of participant nurses had commitment to their organization. Meanwhile, nearly about one fourth $(23.2 \%)$ of them didn't have commitment to their organization and differences between the two hospitals were statistically significant, $\mathrm{P}=0.001$.

Transformational leadership styles and its effect on nurses' organizational commitment in the two studied hospital are displayed in table 6. There were statistically significant positive correlation between 
transformational leadership style and organizational commitment in each hospital (King Abdul Aziz and King Faisal hospitals) and a positive correlation in the comparison of two hospitals, $\mathrm{P}=0.000$.

Lastly, table 7 revealed transactional leadership style and its effect on nurses' organizational commitment in the two studied hospital. There were positive correlation between transactional leadership style and organizational commitment in King Abdul Aziz hospital. On the other hand, there were statistically significant positive correlation between transactional leadership style and organizational commitment in King Faisal hospital. For comparison between the two hospitals, also there were statistically significant positive correlation between transactional leadership style and organizational commitment, $\mathrm{P}=0.03$.

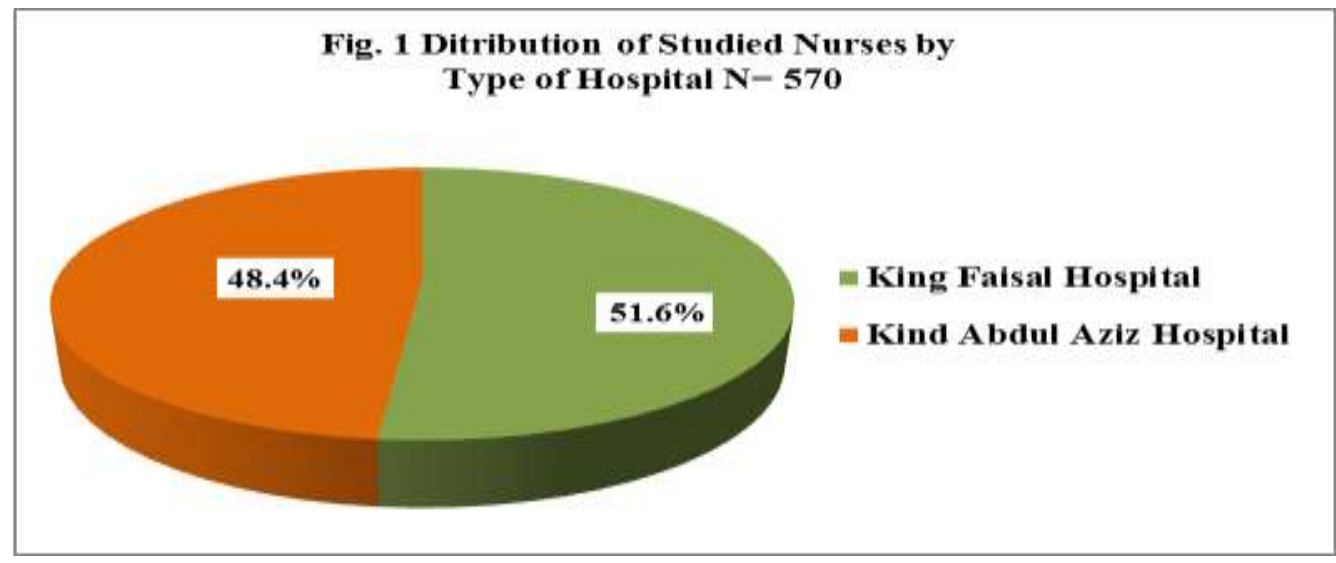

Table 1 (A): Socio- demographic Characteristics of Participant Nurses Distributed by Type of Hospital $(\mathrm{N}=570)$.

\begin{tabular}{|c|c|c|c|c|c|c|c|c|}
\hline \multirow{3}{*}{\multicolumn{2}{|c|}{ Demographic data }} & \multicolumn{4}{|c|}{ Hospitals } & \multirow{2}{*}{\multicolumn{2}{|c|}{ Total }} & $\mathrm{P}$ value \\
\hline & & \multicolumn{2}{|c|}{$\begin{array}{c}\text { King Abdul } \\
\text { Aziz Hospital }\end{array}$} & \multicolumn{2}{|c|}{$\begin{array}{c}\text { King Faisal } \\
\text { Hospital }\end{array}$} & & & \\
\hline & & N0. & $\%$ & No. & $\%$ & No. & $\%$ & \\
\hline \multirow{4}{*}{$\begin{array}{l}\text { Age groups of studied } \\
\text { nurses }\end{array}$} & $20-30$ years & 228 & $82.6 \%$ & 206 & $70.1 \%$ & 434 & $76.1 \%$ & \multirow[t]{3}{*}{$\mathrm{X} 2=17.4, \mathrm{P}=0.000 \mathrm{HS}$} \\
\hline & $31-40$ years & 44 & $15.9 \%$ & 66 & $22.4 \%$ & 110 & $19.3 \%$ & \\
\hline & $41-50$ years & 4 & $1.4 \%$ & 22 & $7.5 \%$ & 26 & $4.6 \%$ & \\
\hline & Mean \pm SD & \multicolumn{2}{|c|}{$28.7 \pm 2.9$ years } & \multicolumn{2}{|c|}{$30.1 \pm 5.2$} & & & $\mathrm{t}=3.8, \mathrm{P}=0.000 \mathrm{HS}$ \\
\hline \multirow[t]{2}{*}{ Gender } & Male & 30 & $10.9 \%$ & 126 & $42.9 \%$ & 156 & $27.4 \%$ & \multirow[t]{2}{*}{$\mathrm{X} 2=73.7, \mathrm{P}=0.000 \mathrm{HS}$} \\
\hline & Female & 246 & $89.1 \%$ & 168 & $57.1 \%$ & 414 & $72.6 \%$ & \\
\hline \multirow[t]{2}{*}{ Occupation } & Staff nurse & 210 & $76.1 \%$ & 262 & $89.1 \%$ & 472 & $82.8 \%$ & \multirow[t]{2}{*}{$\mathrm{X} 2=16.9, \mathrm{P}=0.000 \mathrm{HS}$} \\
\hline & Nurse manager & 66 & $23.9 \%$ & 32 & $10.9 \%$ & 98 & $17.2 \%$ & \\
\hline \multirow{4}{*}{$\begin{array}{l}\text { Experience groups of } \\
\text { nurses' participants }\end{array}$} & $<=5$ years & 126 & $45.7 \%$ & 110 & $37.4 \%$ & 236 & $41.4 \%$ & \multirow[t]{3}{*}{$\mathrm{X} 2=9.5, \mathrm{P}=0.008 \mathrm{Sig}$} \\
\hline & $6-10$ years & 136 & $49.3 \%$ & 150 & $51.0 \%$ & 286 & $50.2 \%$ & \\
\hline & $11-25$ years & 14 & $5.1 \%$ & 34 & $11.6 \%$ & 48 & $8.4 \%$ & \\
\hline & Mean \pm SD & \multicolumn{2}{|c|}{$6.0 \pm 2.4$ years } & \multicolumn{2}{|c|}{$7.2 \pm 4.8$ years } & & & $\mathrm{t}=3.6, \mathrm{P}=0.000 \mathrm{HS}$ \\
\hline \multirow[t]{3}{*}{ Education } & Diploma & 20 & $7.2 \%$ & 96 & $32.7 \%$ & 116 & $20.4 \%$ & \multirow[t]{3}{*}{$\mathrm{X} 2=59, \mathrm{P}=0.000 \mathrm{H} \mathrm{S}$} \\
\hline & Bachelor & 236 & $85.5 \%$ & 174 & $59.2 \%$ & 410 & $71.9 \%$ & \\
\hline & Master & 20 & $7.2 \%$ & 24 & $8.2 \%$ & 44 & $7.7 \%$ & \\
\hline
\end{tabular}

Table 1 (B): Socio- demographic Characteristics of Participant Nurses Distributed by Type of Hospital $(\mathrm{N}=570)$.

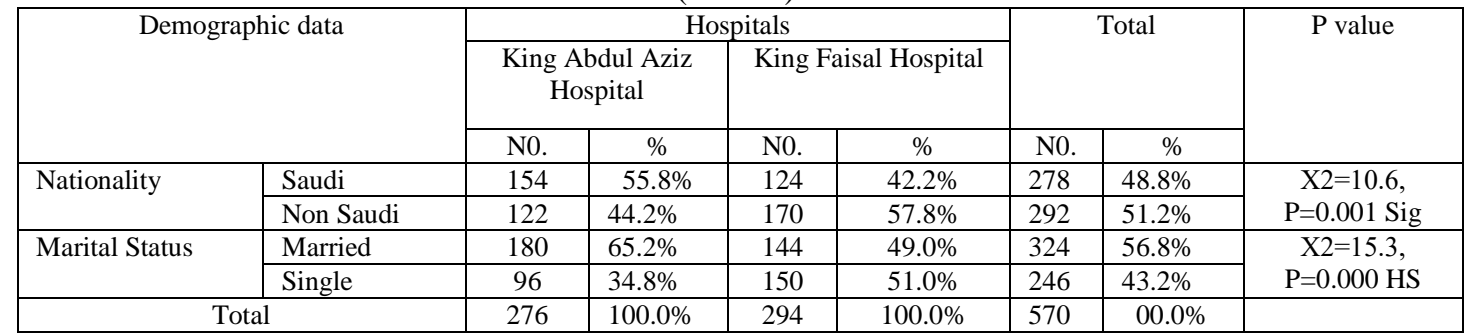


Effect of Nurse Managers' Leadership Styles on Organizational Commitment of Nurses Working at ..

Table 2: Leadership Styles of Nurse Managers Distributed by Type of Hospital (N=570).

\begin{tabular}{|c|c|c|c|c|c|c|c|}
\hline \multirow{2}{*}{ Leadership Styles } & \multicolumn{4}{|c|}{ Hospitals } & \multicolumn{2}{|c|}{ Total } & \multirow{2}{*}{$\mathrm{P}$ value } \\
\hline & \multicolumn{2}{|c|}{$\begin{array}{c}\text { King Abdul Aziz } \\
\text { Hospital } \\
\text { N0. }\end{array}$} & \multicolumn{2}{|c|}{$\begin{array}{c}\text { King Faisal } \\
\text { Hospital } \\
\text { N0. } \quad \%\end{array}$} & N0. & $\%$ & \\
\hline Non transformational leadership style (12 -35) & 90 & $32.6 \%$ & 56 & $19 \%$ & 146 & $25.6 \%$ & $\mathrm{X} 2=13.7$, \\
\hline Transformational leadership style (36 -60) & 186 & $67.4 \%$ & 238 & $81 \%$ & 424 & $74.4 \%$ & $\mathrm{P}=0.000 \mathrm{HS}$ \\
\hline Non transactional leadership style $(6-17)$ & 104 & $37.7 \%$ & 92 & $31.3 \%$ & 196 & $34.4 \%$ & $\mathrm{X} 2=2.6, \mathrm{P}=0.10$ \\
\hline Transactional leadership style $(18-30)$ & 172 & $62.3 \%$ & 202 & $68.7 \%$ & 374 & $65.6 \%$ & NS \\
\hline Total & 276 & $100 \%$ & 294 & $100 \%$ & 570 & $100 \%$ & \\
\hline
\end{tabular}

Table 3: Nurses' Affective Organizational Commitment Distributed by Type of Hospital (N=570).

\begin{tabular}{|c|c|c|c|c|c|c|c|}
\hline \multirow{3}{*}{ Organizational Commitment } & \multicolumn{4}{|c|}{ Hospitals } & \multirow{2}{*}{\multicolumn{2}{|c|}{ Total }} & \multirow[t]{3}{*}{ P value } \\
\hline & \multicolumn{2}{|c|}{ King Abdul Aziz Hospital } & \multicolumn{2}{|c|}{ King Faisal Hospital } & & & \\
\hline & No. & $\%$ & No. & $\%$ & N0. & $\%$ & \\
\hline Non affective commitment $(6-17)$ & 76 & $27.5 \%$ & 46 & $15.6 \%$ & 122 & $21.4 \%$ & $\mathrm{X} 2=11.9$ \\
\hline Affective commitment $(18-30)$ & 200 & $72.5 \%$ & 248 & $84.4 \%$ & 448 & $78.6 \%$ & $\mathrm{P}=0.001 \mathrm{Sig}$. \\
\hline Total & 276 & $100.0 \%$ & 294 & $100.0 \%$ & 570 & $100.0 \%$ & \\
\hline
\end{tabular}

Table 4: Nurses' Continuance Organizational Commitment Distributed by Type of Hospital (N=570).

\begin{tabular}{|c|c|c|c|c|c|c|c|}
\hline \multirow[t]{3}{*}{ Continuance Commitment } & \multicolumn{4}{|c|}{ Hospitals } & \multirow{2}{*}{\multicolumn{2}{|c|}{ Total }} & \multirow[t]{3}{*}{$\mathrm{P}$ value } \\
\hline & \multicolumn{2}{|c|}{ King Abdul Aziz Hospital } & \multicolumn{2}{|c|}{ King Faisal Hospital } & & & \\
\hline & No. & $\%$ & No. & $\%$ & N0. & $\%$ & \\
\hline Non Continuance Commitment (6-17) & 60 & $21.7 \%$ & 30 & $10.2 \%$ & 90 & $15.8 \%$ & $\mathrm{X} 2=14.2$, \\
\hline Continuance Commitment (18-30) & 216 & $78.3 \%$ & 264 & $89.8 \%$ & 480 & $84.2 \%$ & $\mathrm{P}=0.000 \mathrm{HS}$ \\
\hline Total & 276 & $100.0 \%$ & 294 & $100.0 \%$ & 570 & $100.0 \%$ & \\
\hline
\end{tabular}

Table 5: Nurses' Normative Organizational Commitment Distributed by Type of Hospital (N=570).

\begin{tabular}{|c|c|c|c|c|c|c|c|}
\hline \multirow{2}{*}{ Normative commitment } & \multicolumn{4}{|c|}{ Hospital } & \multicolumn{2}{|c|}{ Total } & \multirow{2}{*}{ P value } \\
\cline { 2 - 7 } & \multicolumn{2}{|c|}{$\begin{array}{c}\text { King Abdul Aziz } \\
\text { Hospital }\end{array}$} & \multicolumn{2}{|c|}{ King Faisal Hospital } & \multicolumn{2}{|c|}{} \\
\cline { 2 - 7 } & $\mathrm{N} 0$. & $\%$ & $\mathrm{~N} 0$. & $\%$ & $\mathrm{~N} 0$. & $\%$ & \\
\hline Non normative Commitment(6-17) & 64 & $23.2 \%$ & 98 & $33.3 \%$ & 162 & $28.4 \%$ & $\mathrm{X} 2=7.2$, \\
\hline Normative Commitment(18-30) & 212 & $76.8 \%$ & 196 & $66.7 \%$ & 408 & $71.6 \%$ & P=0.001 Sig. \\
\hline Total & 276 & $100.0 \%$ & 294 & $100.0 \%$ & 570 & $100.0 \%$ & \\
\hline
\end{tabular}

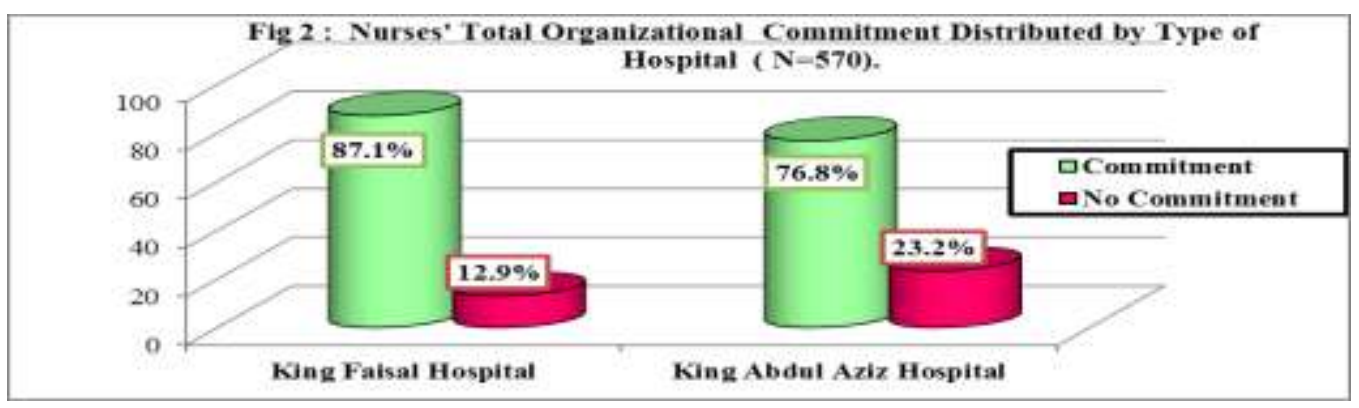

Table 6: Transformational Leadership Styles and its Effect on Nurses' Organizational Commitment in the Two Studied Hospitals.

\begin{tabular}{|c|c|c|c|c|c|c|c|c|c|c|c|c|}
\hline \multirow{5}{*}{$\begin{array}{l}\text { Transformational } \\
\text { Leadership Style }\end{array}$} & \multicolumn{12}{|c|}{ Hospitals } \\
\hline & \multicolumn{6}{|c|}{ King Abdul Aziz Hospital } & \multicolumn{6}{|c|}{ King Faisal Hospital } \\
\hline & \multicolumn{4}{|c|}{ Commitment } & \multirow{2}{*}{\multicolumn{2}{|c|}{$\begin{array}{c}\text { Total Score } \\
\text { Total }\end{array}$}} & \multicolumn{4}{|c|}{ Commitment } & \multirow{2}{*}{\multicolumn{2}{|c|}{$\begin{array}{c}\text { Total Score } \\
\text { Total }\end{array}$}} \\
\hline & \multicolumn{2}{|c|}{$\begin{array}{c}\text { No } \\
\text { commitment } \\
(18-54) \\
\end{array}$} & \multicolumn{2}{|c|}{$\begin{array}{l}\text { Commitment } \\
(55-90)\end{array}$} & & & \multicolumn{2}{|c|}{$\begin{array}{l}\text { No commitment } \\
\quad(18-54)\end{array}$} & \multicolumn{2}{|c|}{$\begin{array}{l}\text { Commitment } \\
(55-90)\end{array}$} & & \\
\hline & N0. & $\%$ & N0. & $\%$ & N0. & $\%$ & N0. & $\%$ & N0. & $\%$ & N0. & $\%$ \\
\hline $\begin{array}{l}\text { Non transformational } \\
\text { leadership style }(12-35)\end{array}$ & 64 & $71.1 \%$ & 26 & $28.9 \%$ & 90 & $100.0 \%$ & 32 & $57.1 \%$ & 24 & $42.9 \%$ & 56 & $100 \%$ \\
\hline $\begin{array}{l}\text { Transformational } \\
\text { leadership style (36-60) }\end{array}$ & 0 & $0 \%$ & 186 & $100.0 \%$ & 186 & $100.0 \%$ & 6 & $2.5 \%$ & 232 & $97.5 \%$ & 238 & $100 \%$ \\
\hline Total & 64 & $23.2 \%$ & 212 & $76.8 \%$ & 276 & $100.0 \%$ & 38 & $12.9 \%$ & 256 & $87.1 \%$ & 294 & $100 \%$ \\
\hline
\end{tabular}

For King Abdul Aziz hospital: $\mathrm{X} 2=172.0, \mathrm{P}=0.000$ High Significant.

For King Faisal hospital: X2 $=120.0, \mathrm{P}=0.000$ High Significant.

For comparison between King Abdul Aziz and King Faisal hospitals: X2=18.2, $\mathrm{P}=0.000$ High Significant. 
Effect of Nurse Managers' Leadership Styles on Organizational Commitment of Nurses Working at ..

Table 7: Transactional Leadership Style and its Effect on Nurses' Organizational Commitment in the Two Studied Hospitals.

\begin{tabular}{|c|c|c|c|c|c|c|c|c|c|c|c|c|}
\hline \multirow{5}{*}{$\begin{array}{c}\text { Transactional } \\
\text { Leadership Style }\end{array}$} & \multicolumn{12}{|c|}{ Hospitals } \\
\hline & \multicolumn{6}{|c|}{ King Abdul Aziz Hospital } & \multicolumn{6}{|c|}{ King Faisal Hospital } \\
\hline & \multicolumn{4}{|c|}{ Commitment total score } & \multirow{2}{*}{\multicolumn{2}{|c|}{ Total }} & \multicolumn{4}{|c|}{ Commitment total score } & \multirow{2}{*}{\multicolumn{2}{|c|}{ Total }} \\
\hline & \multicolumn{2}{|c|}{$\begin{array}{c}\text { No } \\
\text { commitment } \\
(18-54)\end{array}$} & \multicolumn{2}{|c|}{$\begin{array}{l}\text { Commitment } \\
(55-90)\end{array}$} & & & \multicolumn{2}{|c|}{$\begin{array}{c}\text { No } \\
\text { commitment } \\
(18-54)\end{array}$} & \multicolumn{2}{|c|}{$\begin{array}{l}\text { Commitment } \\
(55-90)\end{array}$} & & \\
\hline & NO & $\%$ & N0. & $\%$ & N0. & $\%$ & N0. & $\%$ & N0. & $\%$ & N0. & $\%$ \\
\hline $\begin{array}{l}\text { Non transactional } \\
\text { leadership style }(6-17)\end{array}$ & 18 & $17.3 \%$ & 86 & $82.7 \%$ & 104 & $100.0 \%$ & 2 & $2.2 \%$ & 90 & $97.8 \%$ & 92 & $100.0 \%$ \\
\hline $\begin{array}{l}\text { Transactional leadership } \\
\text { style }(18-30)\end{array}$ & 46 & $26.7 \%$ & 126 & $73.3 \%$ & 172 & $100.0 \%$ & 36 & $17.8 \%$ & 166 & $82.2 \%$ & 202 & $100.0 \%$ \\
\hline Total & 64 & $23.2 \%$ & 212 & $76.8 \%$ & 276 & $100.0 \%$ & 38 & $12.9 \%$ & 256 & $87.1 \%$ & 294 & $100.0 \%$ \\
\hline
\end{tabular}

For King Abdul Aziz hospital: $\mathrm{X} 2=3.2, \mathrm{P}=0.07$ Not Significant.

For King Faisal hospital: X2 $=13.8, \mathrm{P}=0.000$ High Significant.

For comparison between King Abdul Aziz and King Faisal hospitals: X2=6.5, $\mathrm{P}=0.03$ Significant.

\section{Discussion}

As a priority, the role of the nurse manager, in continually and effectively empowering staff in the care process, is to ensure a work environment and culture that encourages and sustains quality of healthcare and patient safety. Effective leadership comprises enabling ordinary people to produce extraordinary performance in face of challenge and change, and maintenance of constant performance and benefits. Furthermore, leadership in healthcare organizations is considered an important element for assuring quality health care services, patient satisfaction, and employee performance (Aboshaiqah et al., 2014). However, the relationship between leadership style and employee commitment has not been investigated enough in Saudi Arabian health care context. This cross-sectional descriptive study included 570 nurses, with the aim of exploring and describing nurse managers' leadership styles and its effect on nurses' organizational commitment at Taif governmental hospitals in Kingdom of Saudi Arabia tried to.

The present study's findings revealed that transformational leadership style was rated higher than transactional leadership styles in both hospitals, and there were statistically significant positive correlations between the perceived transformational and transactional leadership styles from nurses' point of view. This result was consistent with $\boldsymbol{O m e r}$ (2005) who reported that the transformational leadership style has been ranked higher by the nurses compared to transactional leadership style, and there were significant correlations between the perceived leadership style and organization outcomes. Moreover, this finding was congruent with Moussa et al., (2016) who revealed that Saudi nurses perceived their managers as transformational rather than transactional leaders.

The results further showed that transformational leadership was associated with job satisfaction. Transactional leadership on the other hand was found to be associated with job dissatisfaction. Also, the result suggested that leaders using the components of transformational leadership more likely contribute to a positive work environment, increased job satisfaction, commitment and motivation. Likewise, Ahmad et al., (2013) mentioned that transformational leadership have higher mean compared to transactional leadership which means that transformational leadership style is more acceptable for nurses compared to transactional leadership style.

In addition, the result of this study revealed that transformational leadership style is more effective than transactional leadership style in producing organizational commitment. This result was supported by Ahmad et al., (2015) who found that transformational leadership style is more valuable than transactional, $\beta=0.6381$, tvalue $=10.874$ and $p$-value $<0.01$. It is also evident from the finding that the relationship between transactional leadership style and organizational commitment is positive, but less effective than transformational leadership style on organizational commitment in public Tertiary Institutions in Pakistan. Furthermore, Limsila and Ogunlana (2007) found that the leadership style mostly adopted and proving to be most suitable for that people is the transformational leadership. Meanwhile, the result was in the same line with Abualrub and Alghamdi (2012) who stated that Saudi nurses perceived their managers as transformational rather than transactional leaders. The results further showed that transformational leadership was associated with job satisfaction. Transactional leadership on the other hand was found to be associated with job dissatisfaction. Nurses who were satisfied with their jobs intended to stay longer. In addition, Alshahrani and Baig (2016) indicated that nurses working under leaders with higher transformational style of leadership had more job satisfaction compared to nurses working under leaders with higher scores on transactional style of leadership. Organizational outcomes were better with transformational style of leadership. Also, it is found that transformational leadership is playing a positive role in Pakistani companies and employees in those organizations where transformational leaders seem to be more satisfied with their jobs than those of transactional leadership (Mahmood, 2015). Moreover, 
Jain and Duggal (2015) reported a strong and positive relationship between transformational leadership and organizational commitment. Conversely, these results were in contrast with Alshahrani and Baig ( 2016) who mentioned that most of the head nurses demonstrated transactional leadership style compared to the transformational style of leadership, also, the result was reinforced by the findings of previous studies (Bass and Avolio 2004). Likewise, the findings of this study were on contrary with Lorber et al., (2016) who revealed that leaders most widely use the transactional leadership style. They also identified statistically significant differences in the assessment of the transactional leadership style between leaders and other employees in nursing.

Leadership is a very important variable which enhances organizational commitment of the employees (Aabdeen et al., 2016). Effective leaders should engage in both transformational and transactional behaviors(Keskes, 2014). The results of this study demonstrated that, there were a statistically significant positive correlation between both (transactional and transformational) leadership styles and organizational commitment. These findings were similar with Dariush et al., (2016) who stated that there is a positive relationship between transformational leadership style consisting of the creation of the trust, induction of a common vision, encouragement of creation and emphasis on progress, and organizational commitment. Also, there has often been a significant relationship between leadership styles and a variety of organizational commitments. In accordance with the study result, Rehman et al., (2012) showed that both transformational and transactional leadership have positive relationship with organizational commitment. The second important finding is that transformational leadership is used mostly than transactional leadership.

Likewise, Njoroge, et al.,(2015) conducted an empirical study on 343 respondents of technical institution, Kenya to determine the effect of transformational leadership style on organizational commitment as moderated by employee participation. The result revealed that transformational leadership is a significant predictor of affective, continuance and normative commitment. In addition, Hill et al., (2012) found that there was a positive relationship between leader's behavior and employees' commitment. In agreement with the findings of other studies, Aghashahi, et al.,( 2013) examined the statistical relationship between leadership styles and organizational commitment components and found a positive direct relationship of transformational leadership style with affective and normative commitment in the context of service industry.

Moreover, these results were congruent with Marmaya et al., (2011) who showed that transformational and transactional leadership have positive relationship with employees' organizational commitment while employees of Malaysian organization are more influenced by transformational than transactional. Also, the results were in the same line with Asiri et al., ( 2016) who revealed that transformational, transactional and laissez-faire styles positively affect commitment levels, with the transformational style having a marginal effect. In the same context, Lee (2010) asserted that transformational leadership and transactional leadership both have a positive and significant effect on organizational commitment. Moreover, organizational commitment will significantly and positively affect to job performance. Also, Ramezaninezhad et al., (2011) pointed out that transformational and transactional leadership styles have significant positive effects on the organizational commitment of school sports teachers. Similar findings were reported by Lotfi et al., (2012), when they found that there is positive relationship between transformational and transactional leadership styles and organizational commitment; the only difference was that their study was concerned with faculty members.

In addition, these finding was consistent with Othman et al., (2013) who concluded that there is a positive correlation between leadership styles and organizational commitment. Researchers contended that leaders can be both transformational and transactional and that leader's actions within organization contribute significantly to employee's organizational commitment. The finding was also congruent with Rao and Gorfie (2017) who indicated that transformational and transactional leadership styles are positively and significantly correlated with organizational commitment. However, the correlation among these constructs is very weak; indicating that all the components of transformational leadership, and transactional leadership could not as such strongly promote the increment of organizational commitment of faculties. The result showed that transformational leadership style explained the variance on organizational commitment better than transactional and laissez faire leadership behaviors demonstrated by heads and deans.

In the same line, the results from this study were supported by Lee (2004) who found out that transformational leadership correlates significantly with organizational commitment with samples of research and development professional in Singapore. Likewise, Porter (2015) reported that transformational leadership was significantly correlated with organizational commitment. In this respect, Stacey (2007) also drew the conclusion that both transformational and transactional leadership styles have positive effects on the affective and normative commitments. Moreover, Hayward et al., (2004) noted that transformational leadership has moderate positive correlation with affective commitment. In addition, their result reveals that transformational leadership style is likely to generate commitment from subordinates while transactional and laissez-faire are not. Meanwhile, Dargahi et al., (2017) pointed out that there was a positive relationship between spiritual leadership with organizational commitment $(\mathrm{P}=0.000)$. 
Likewise, Lai et al., (2014) probed the relationship between school teacher commitment and principle leadership styles in Perak, Malaysia. The result found that the relationship between commitment and transformational leadership style is significant. Another recent research by Shin (2013) also investigated the association between organizational outcome, organizational commitment and leadership style in fire department. The findings showed that both styles of leadership (transformational and transactional leadership) have significant relationship with organizational commitment. Moreover, Chiun et al., (2009) highlighted that both styles of leadership (transformational and transactional) have effect on organizational commitment. However, transactional leadership style helps in some positions but less effective than transformational leadership style.

In addition, the result was similar with Ahmad et al., (2015) who stated that the relation between transformational leadership style and organizational commitment is significant. This finding is consistent with results of previous research (Cemaloglu, et al., 2012). The finding also revealed that the relationship between transactional leadership and organizational commitment is significant. The finding is also supported by the previous researches results (Yavirach, 2012 and Madanipour, 2013).

In contradiction with the present study finding, Lee (2004) pointed out that transactional leadership does not have significant relationship with organizational commitment. Moreover, Hayward et al., (2004) indicated that no correlation was found between transactional leadership and affective, normative and continuance commitment. However, disagreement arises as Epitropaki and Martin (2005) and Wu (2009) declared that transactional leadership is more effective than transformational leadership style to achieve organizational goals and enhance employee commitment. Similarly, Marmaya et al., (2011) also argued that the relationship between employee commitment and transactional leadership is more significant than transformational leadership style.

Finally, and away from the strong emphasis on transformational leadership style and organizational commitment, and the weak emphasis on transactional leadership style, one positive thing was certain from the present study' findings. The majority of participant nurses appreciated the importance of leadership styles of nurse managers to produce organizational commitment, improve and upgrade the effectiveness of the delivered services. Nursing leaders need to utilize a leadership style that best suit the environment and their subordinates. The leader should be able to recognize and analyze their subordinates as well as the environment where they worked. Leaders' behavior is reflected through their employees in the care they give to their patients each day, regardless of the leadership style used. Also, healthcare organizations need nursing leaders who can improve nursing care, are an advocate for the nursing profession, and have a positive effect on health care.

\section{Conclusion}

Generally, nurses working under transformational and transactional leaders tend to be more loyal to their organizations. The present study's findings revealed that transformational leadership style was rated higher than transactional leadership style in both hospitals, and there were statistically significant positive correlations between the perceived leadership styles and organizational commitment. The great majority of studied nurses had commitment to their organization. Moreover, only small percentage of them didn't have commitment to their organization. Managers should use more principles of these styles of leadership to increase the level of organizational commitment of their employees.

\section{Recommendations}

Based on the findings of this study, the following recommendations are proposed:

1. Designing and implementing a comprehensive training program to managers and leaders to encourage behaviors such as trust creation, induction of a common vision, encouragement of creativity, emphasis on personal development, and achieving organizational and individual achievements and benefits. Such managers can play a key role in the development of organizational commitment of their employees.

2. Nursing leaders in hospitals can enhance the nursing work environment by practicing appropriate leadership styles and empowering strategies, including greater participation of nursing staff in the decision making process. Ultimately, more effective nursing management should result in improved nursing staff retention, job satisfaction, and work commitment.

3. Replication of this study in different health care sectors with other healthcare professionals and in critical care units will be beneficial, variables such as empowerment, job satisfaction, turnover, and retention can be considered in future research to increase organizational commitment of employees.

\section{Acknowledgements}

Our thanks are submitted first and foremost to Allah who gave us the strength and ability to complete this work. We wish to express our indebtedness and our gratitude to Taif University for giving us the opportunity to pursue this research. I would like to express my thanks to professor Dr. Laila Shehata Dorgham for her kind help, constant encouragement, constructive criticism, generous advice, and the effort and time she 
has devoted to the fulfillment of this work. Our sincere gratitude and appreciation are also extended to King Abdul Aziz and King Faisal hospitals for their support and assistance in data collection. It is a great pleasure to thank every Nurse for their cooperation and help during data collection.

\section{References}

[1] Aabdeen, Z., Khan, M.N., Khan, H. G., Farooq, H. Q., Salman, M. and Rizwan, M. (2016). The Impact of Ethical Leadership, Leadership Effectiveness, Work Related Stress and Turnover Intention on the Organizational Commitment. International Journal of Economics and Business Administration; 2(2): 7-14.

[2] Aboshaiqah, A., Hamdan-Mansour, A., Sherrod, D., Alkhaibary, A. and Alkhaibary, S. (2014). Nurses' Perception of Managers' Leadership Styles and Its Associated Outcomes." American Journal of Nursing Research; 2(4): 57-62.

[3] Abualrub, R.F. \& Alghamdi, M.G. (2012). The Impact of Leadership Styles on Nurses' Satisfaction and Intention to Stay Among Saudi Nurses. Journal of Nursing Management; 20 (5): 668-678.

[4] Aghashahi, B., Davarpanah, A. Omar, R., and Sarli, M. (2013).The Relationship Between Leadership Style and Organizational Commitment: A Survey in a Malaysian Contact Centre. Interdisciplinary Journal of Research in Business; 2 (11): 1-7.

[5] Ahmadi, S.A., Ahmadi, F. and Zohrabi, M. (2012). Effect of the Leadership Styles on the Organizational Commitment Given the Staff Personality Traits. Interdisciplinary Journal of Contemporary Research in Business; 4(1): 247-264.

[6] Ahmad, A., Adi, M. N., Noor, H. M., Abdul Rahman, A. and Yushuang, T. (2013). The Influence of Leadership Style on Job Satisfaction among Nurses. Asian Social Science, 9 (9): 172-178.

[7] Ahmad, A., Abdul Majid, A. and Zin, M. (2015). The Measurement of the Effectiveness of Leadership Styles for Organizational Commitment in Pakistan. Asian Social Science; 11(25): 135-143.

[8] Alkahtani, A. H. (2016). The Influence of Leadership Styles on Organizational Commitment: The Moderating Effect of Emotional Intelligence. Business and Management Studies; 2(1): 23-34.

[9] Alshahrani, F. M. and Baig, L. A. ( 2016). Effect of Leadership Styles on Job Satisfaction Among Critical Care Nurses in Aseer, Saudi Arabia. Journal of the College of Physicians and Surgeons Pakistan; 26 (5): 366-370.

[10] Allen, N. J., \& Meyer, J. P. (1997). Commitment in the Workplace: Theory, Research and Application. Thousand Oaks, CA: Sage Publications.

[11] Asiri, S. A., Rohrer, W. W., Al-Surimi, K., Da'ar, O.O. and Ahmed, A. (2016). The Association of Leadership Styles and Empowerment with Nurses' Organizational Commitment in an Acute Health Care Setting: A Cross-Sectional Study. BMC Nursing; 15 (38): 1-10.

[12] Bass, B., and Avolio, B. (2004). Manual for Multifactor Leadership Questionnaire: Sampler Set. $3^{\text {rd }}$ ed. Redwood: Mind Garden Inc.

[13] Cemaloglu, N., Sezgin, F., \& Kiling, A. C. (2012). Examining the Relationships between School Principals Transformational and Transactional Leadership Styles and Teachers Organizational Commitment. The Online Journal of New Horizons in Education; 2(2): 53-64.

[14] Chiun Lo, M., Ramayah, T., \& Min, H. (2009). Leadership Styles and Organizational Commitment: A Test on Malaysia Manufacturing Industry. African Journal of Marketing Management; 1(6): 133-139.

[15] Dariush, L., Choobdar, G., Valadkhani, P. and Mehrali, E. (2016). Leadership Styles Facilitating Organizational Commitment of Employees. International Journal of Economics; Commerce and Management, United Kingdom; 4(5): 640-655.

[16] Dargahi, H., Nasrollahzaedeh, A. K. and Rahmani, H. (2017). An Investigation of the Relationship Between Spiritual Leadership Style With Organizational Commitment Among Tehran University of Medical Sciences Staff. International Journal of Asian Social Science; 7(3): 234-241.

[17] Epitropaki, O., \& Martin, R. (2005). From Ideal to Real: A Longitudinal Study of the Role of Implicit Leadership theories on Leader-Member Exchanges and Employee Outcomes. Journal of Applied Psychology; 90(4): 659-676. http://dx.doi.org/10.1037/0021-9010.90.4.659.

[18] Fabiene, E.E. and Kachchhap, S. L. (2016). Determinants of Employee's Commitment among Healthcare Professionals. International Journal of Academic Research in Accounting, Finance and Management Sciences; 6(2): 44-52.

[19] Foon, M.S. (2016). A Conceptual Framework of Transformational and Transactional Leadership on Nurse Educators Job Satisfaction, International Journal of Social Science and Humanities Research; 4 (1): 596-605.

[20] Fugate, K. (2014). Transformational Nursing Leadership and Effects on Job Satisfaction: An Integrated Literature Review. University of Central Florida.

[21] Gates, B. (2009). The Inspiration Leader. Retrieved 15 $5^{\text {th }}$ May, 2011, from www.writework com/essay/bill-gates-Inspirational Leader.

[22] Haghighy, M., Kivahed, A. and Shahrakimojahed, L. (2016). Predicting Different Dimensions of Organizational Commitment in the Red Crescent Society of Fars Province Directors and Staff Based on Dimensions of their Emotional Intelligence and Organizational Culture. Indian Journal of Fundamental and Applied Life Sciences; 6(2): 44-54.

[23] Hayward, Q., Goss, M. and Tolmay, R. (2004). The Relationship between Transformational and Transactional Leadership and Employee Commitment. Grahams Town: Rhodes University, Business Report. Business Report.

[24] Hill, N. S., Seo, M. G., Kang, J. H., and Taylor, M. S. (2012). Building Employee Commitment to Change Across Organizational Levels: The Influence of Hierarchical Distance and Direct Managers' Transformational Leadership. Organization Science, 23(3):758-777. http://dx.doi.org/10.1287/orsc.1110.0662

[25] Huber, D. L. (2014). Leadership \& Nursing Care Management (6 ${ }^{\text {th }}$ ed.). Retrieved from http://www.google.si/books?hl=sl\&lr=\&id=CZx.

[26] Ingram, D. (2016). Transformational Leadership Vs. Transactional Leadership Definition.

[27] Jain, P. and Duggal, T. (2015). The Role of Transformational Leadership in Organizational Commitment. International Journal of Business Quantitative Economic and Applied Management Research; 2(5): 1-11.

[28] Keskes, I. (2014). Relationship between Leadership Styles and Dimensions of Employee Organizational Commitment: A Critical Review and Discussion of Future Directions. Intangible Capital; 10(1): 26-51.

[29] Kimura, T. (2013). The Moderating Effects of Political Skill and Leader-Member Exchange on the Relationship Between Organizational Politics and Affective Commitment. Journal of Business Ethics; 116(3): 587- 599

[30] Kuria, L.K., Namusonge, G. S. and Iravo, M. (2016). Effect of Leadership on Organizational Performance in Health Sector. International Journal of Scientific and Research Publications; 6 (7): 658-663.

[31] Lai, T. T., Luen, W. K., Chai, L. T., \& Ling, L. W. (2014). School Principal Leadership Style and Teacher Organizational Commitment Among Performing Schools. International Conference on Business and Economic Research, 208-220. 
[32] Lee, H. W. (2010). Relationship Between Leadership Style and Organizational Commitment. Operating Management Reviews; 6(1):87-95.

[33] Lee, J. (2004). Effects of Leadership and Leader-Member Exchange on Commitment. Leadership and Organization Development Journal; 26: 655-672. http://dx.doi.org/10.1108/01437730510633728.

[34] Limsila, K. and Ogunlana, S. O. (2007). Performance and Leadership Outcome Correlates of Leadership Styles and Subordinate Commitment. Engineering, Construction and Architectural Management, 15(2):164-184. http://dx.doi.org/10.1108/09699980810852682.

[35] Lorber, M., Treven, S. and Mumel, D. (2016). The Examination of Factors Relating to the Leadership Style of Nursing Leaders in Hospitals. Nase gospodarstvo / our Economy; 62(1): 27-36.

[36] Lotfi, F., Mokhtarpour, S., Momenirad, A., Amini, M. and Kojuri, J. (2012). Relevance Between Leadership Style and Organizational Commitment of Faculty Members. Medical Journal of Hormozgan University; 16 (3) : $233-239$.

[37] Madanipour, M. (2013). The Influence of Attachment Style on the Relationship Between Leadership, Organizational Commitment, and Organizational Citizenship Behavior. Alliant International University. Dissertation.

[38] Malloy, T., \& Penprase, B. (2010). Nursing Leadership Style and Psychosocial Work Environment. Journal of Nursing Management; 18(6): 715-725. doi: 10.111/j.1365-2834.2010.01094.x.

[39] Manetje, O. and Martins, N. (2009). The Relationship between Organizational Culture and Organizational Commitment. Southern African Business Review, 13(1): 87-111.

[40] Marquis, B. L., \& Huston, C. J. (2015). Leadership Roles and Management Functions in Nursing: Theory and Application (7 ${ }^{\text {th }}$ ed.). Philadelphia: Wolters/Kluwer/Lippincott Williams and Wilkins.

[41] Marmaya, N. H., Hitman, M., Torsiman, N. N. \& Balakrishnan, B. (2011). Employee's Perception of Malaysian Managers' Leadership Styles and Organizational Commitment. African Journal of Business Management; 5(5): 1584-1588.

[42] Meyer, J. T. C.M. (2004). Employee Commitment Survey. University of Waster. Online Proceeding: http://www.flintbox.com/searchresults.asp.

[43] Mohmood, A. (2015). Effects of Leadership Styles on Organizational Commitment in Public and Private Sectors of Pakistan. Master Thesis, University of Agder, School of Business and Law.

[44] Moussa, M., Aboshaiqah, A., and Al Otaibi, A. (2016). Effect of Nurse's Supervisor's Leadership Style on Nurse's Job Satisfaction. Swift Journal of Nursing and Midwifery; 2(2): 19-25.

[45] Njoroge, D., Gachunga, H. and Kihoro, J. (2015). Transformational Leadership Style and Organizational Commitment: The Moderating Effect of Employee Participation. Journal of Management; 2(6): 94-107.

[46] Northouse, P. G. (2015). Leadership: Theory and Practice. Thousand Oaks, CA: Sage Publications. Parasuraman, S., \& Nachman, S. A. (1987). Correlates of Organizational and Professional Commitment The Case of Musicians in Symphony Orchestras. Group \& Organization Management;12(3): 287-303.

[47] Omer, T.Y. (2005). Leadership Style of Nurse Managers at the Saudi National Guard Hospitals [Dissertation]. United States: George Mason University.

[48] Othman, J., Mohamed, K. A. and Silva, J. (2013). Does a Transformational and Transactional Leadership Style Predict Organizational Commitment among Public University Lecturers in Nigeria? Asian Social Science; 9(1): 165-170.

[49] Porter, J.A. (2015). The Relationship between Transformational Leadership and Organizational Commitment in Nonprofit Long Term Care Organizations: The Direct Care Worker Perspective. Creighton Journal of Interdisciplinary Leadership; 1(2): 68-85.

[50] Raja A. S. \& Palanichamy P. (2011) Leadership Styles and Its Impact on Organizational Commitment, The Journal of Commerce, Vol. 3, No. 4, ISSN: 2218-8118, 2220-6043

[51] Ramezaninezhad, R. Hematinezhad, M.A, Andam, R. Zare, S. and Sadeghpoor, N. (2011). Relationship between Ttransformational and Transactional Leadership Styles of School Principals and Sports Teachers' Organizational Commitment. Journal of Kinematic Behavior and Sport Management; 1 (3): 63-72.

[52] Rao, G. S. and Gorfie, G. T. (2017). The Effect of Leadership Styles on Organizational Commitment: A Study of Ethiopian Public Universities. ZENITH International Journal of Multidisciplinary Research; 7(1): 98- 116.

[53] Rego, P., Lopes, M. P. and Nascimento, J. L. (2016). Authentic Leadership and Organizational Commitment: The Mediating Role of Positive Psychological Capital. Journal of Industrial Engineering and Management; 9(1): 129-151.

[54] Rehman, S., Shareef, A., Mahmood, A., and Ishaque, A. (2012). Perceived Leadership Styles and Organizational Commitment. Interdisciplinary Journal of Contemporary Research in Business; 4(1): 616-626.

[55] Roussel, L., Swansburg, R. C., and Swansburg, R. J. (2009). Management and Leadership for Nurse Administrators (5 ${ }^{\text {th }}$ ed.). Sudbury, MA: Jones and Bartlett Publishers.

[56] Shin, Y. (2013). The Relationship Between Leadership Styles, Organizational Commitment, and Organizational Outcome in Oklahoma's Volunteer Fire Departments. Oklahoma State University.

[57] Soha, H. M., Osman, A., Abdul Manaf, A. H. and Abdullah, M. S. (2016). Leadership Styles Affecting The Individuals' Commitment: A Study of the Public University in Northern State of Malaysia. Asian Journal of Social Sciences \& Humanities; 5(1): 80-86.

[58] Sow, M., Anthony, P. and Berete, M. (2016). Normative Organizational Commitment and Its Effect on Employee Retention. Business \& Economic Research; 6(1): 137-147.

[59] Stacy, A. M. (2007). Training future leaders. In C. M. Golde, \& G. E. Walker (Eds.), Envisioning the future of doctoral education: Preparing stewards of the discipline (pp. 187-206). San Francisco: Jossey-Bass.

[60] Sullivan, E. J., \& Garland, G. (2010). Practical Leadership and Management in Nursing. Harlow: Pearson Education Limited.

[61] Vera, D. \& Crossan, M. (2004). Strategic Leadership and Organizational Learning. Academy of Management Review; 29 (2): 222240.

[62] Walumbawa, F.O., Orwa, B., Wang, P. and Lawler, J.J. (2005). Transformational Leadership, Organizational Commitment, and Job Satisfaction: A Comparative Study of Kenyan and U.S. Financial Firms. Human Resource Development Quarterly; 16(2): 235-256. http://dx.doi.org/10.1002/hrdq.1135.

[63] Wu, F. (2009). The Relationship between Leadership Styles and Foreign English Teachers Job Satisfaction in Adult English Cram Schools: Evidences in Taiwan. The Journal of American Academy of Business, Cambridge;14(2): 18-25.

[64] Yavirach, N. (2012). The Impact of Transformational and Transactional Leadership to Subordinates' Job Satisfaction, Organizational Commitment Affect to Team Effectiveness. Organizational Commitment Affect to Team Effectiveness (October 9, 2012). http://dx.doi.org/10.2139/ssrn.2159035. 